\title{
The Effects of Marital Status of Hair and Beauty Industry Workers on Strategies to Cope with Violence and Resilience
}

\author{
In-sun No ${ }^{1}$, Dong-geun Kim ${ }^{2, *}$, and Eun-jeong $\mathrm{Choi}^{3}$ \\ ${ }^{1} \mathrm{CEO}$, Director of Sun Hair Design and Management Institution \\ ${ }^{2}$ Graduate Student, Department of Health Cosmetic, Dongduk Women's University Graduate School \\ ${ }^{3}$ Associate Professor, Dept. of Beauty Arts, Jeonghwa Arts College
}

\section{모발 미용산업 종사자의 결혼유무가 폭력대응 전략이 회복력에 미치는 영향}

\author{
노인선 ${ }^{1} \cdot$ 김동근 ${ }^{2, *} \cdot$ 최은정 ${ }^{3}$ \\ 1선(Sun)헤어디자인경영연구소, 원장 \\ 2동덕여자대학교 일반대학원 보건향장학과, 대학원생 \\ 3정화예술대학교 미용예술학부, 부교수
}

\begin{abstract}
Workers in the customer service industry including hair and beauty industry workers and department store employees are recently dealing with an increasing need for the supply of excessive services by companies as well as unreasonable demands from consumers. As such, service industry workers who deal with customers are going through not only physical but also verbal and emotional abuse. This study discusses the influences of violence experiences of hair and beauty industry workers on their resilience, an ability to recover, associated with individual characteristics. For such purpose, a total of 247 structured questionnaires obtained from a face-to-face survey of male and female hair and beauty industry workers in their 20s, 30s, 40s and 50s from Gangbuk and Gangnam District of Seoul Metropolitan City on the influences of experiences of violence from customers on resilience were analyzed. The purpose of this study is to test the influences of violence experiences of hair and beauty industry workers on resilience in association with their general characteristics, and thus analysis of collected data was performed by frequency analysis, testing of reliability with Cronbach's alpha, descriptive statistics, ttest, correlation analysis and multiple regression analysis in SPSS 21.0. The results of this study on violence experiences of hair and beauty industry workers associated with general characteristics suggested that, with respect to age, people in their $20 \mathrm{~s}$ and $30 \mathrm{~s}$ had a higher level of internal violence experiences than those in their 40s. As to marital status, married people were found to have a higher level of violence experiences than unmarried people. Married people also showed a higher level of resilience associated with general characteristics than unmarried people, which seems the consequence of differences in their ability to communicate with customers and cope with their work based on their career. Therefore, this study implies that there is a need for the utilization of various educational programs which can help hair and beauty industry workers develop their ability to recover by themselves, as well as protection from their work environment and improvements in their relationships with superiors or colleagues in the workplace due to the nature of hair and beauty industry.
\end{abstract}

Keywords: Hair and beauty industry workers, resilience, verbal abuse, violence experience

\section{Introduction}

An increasing number of service industry workers including workers in the hair and beauty industry and department store

*Corresponding author: Dong-geun Kim

Tel : +82-2-6916-3205

E-mail : kimdonggueun70@hanmail.net

접수일(2021년 2월 9일)/수정일(2021년 4월 20일)/채택일(2021년 6월 9일) employees are recently facing severe verbal and physical abuse as well as unreasonable demands from customers due to company policies of excessive customer services (Lim, 2014). This phenomenon is in line with the fact that there currently are around 6 million emotional labor workers whose mental health is being threatened at work (Kim, 2014). Similarly, widespread experiences of violence reached a serious level in medical institutions where nurses, who have 
been through mostly physical and verbal abuse, account for 95.5\% of the victims (Wu et al., 2018).

It was found that service industry workers who have an experience of violence go through negative feelings such as anger, anxiety and depression, along with changes in their interpersonal relationships and physical and mental side effects including nervousness (Wu et al., 2018).

Besides, verbal abuse was defined as a behavior which gives an unpleasant feeling to the listeners or psychologically suppresses the listeners using negative words and actions with offensive words of an accusatory or aggressive tone (Lee et al., 2017). It was found that verbal abuse causes incurable chronic stress which leads to physical and mental exhaustion.

Verbal abuse not only threatens an individual's physical and emotional stability and interferes with task management in the workplace, but also decreases the efficiency of human resources within an organization and therefore has a bad influence on organizational productivity (Lee et al., 2017). As such, since verbal abuse is a factor that threatens an individual's health and interferes with organizational efficiency and business productivity, there is a need for an attempt to deal with an experience of violence inside and outside the workplace.

Besides, the nature of hair and beauty industry which features the beauty of technology and art being combined requires professional human services for customers. In particular, since there is a need for the achievement of customer satisfaction with techniques which suit customer tastes in an ultimate emotional space, failure to satisfy customers with direct face-to-face services can even cause stress due to individual characteristics. Therefore, workers in the hair and beauty industry are more likely to be exposed to verbal and emotional abuse, and consequently their mental health and physical stress is currently emerging as a serious problem (Lee, 2018). Regarding the factors related to the status of violence experience among wage workers in the workplace in Korea, personal characteristics were classified into gender, age and education level for the understanding of workplace violence experience (Hong, 2019). However, few studies on emotional and verbal abuse have been conducted in the area of hair and beauty, while there are a number of studies on the issue in many other areas.

In conclusion, hair and beauty industry workers need an ability to deal with such situations by controlling their emotions and recover by themselves. In this regard, the purpose of this study is to understand the effects of emotions that hair and beauty industry workers experience in the course of physical and mental recovery after external and internal verbal abuse on resilience and further use the results of this study as the basis for the improvement of hair and beauty industry workers' mental health and physical relaxation.

\section{Theoretical Background}

\section{Definition of Violence}

In today's society, people are becoming more aggressive and showing violent behaviors more frequently in interpersonal relationships than ever with an increase in the degree of frustration and control over individuals along with drastic social changes (Kang \& Park, 2015). In the case of workplace violence in particular, an individual who experienced violence from colleagues or superiors needs to continue working with the assailants, which brings the issue of infringement of not only human rights but also workers' rights (Kim, 2002). In accordance with the factors related to the status of violence experience among wage workers in the workplace in Korea, a large proportion of young and middle-aged male workers experienced physical violence, and most of the middle-aged female workers experienced sexual harassment, with gender and age, among personal characteristics, being the major causes of differences (Hong, 2019).

People who faced verbal abuse which occurs without just cause or in unexpected situations at work go through a series of emotions including embarrassment, shame, anger, shock and astonishment. Repeated exposure to such circumstances makes people have feelings such as inferiority, humiliation and hatred and has a bad influence on their mental health in the long term (Bae, 2012). Besides, constant exposure to verbal abuse may interfere with an individual's work performance and even damage a self-concept. Types of violence involve verbal abuse (28.7\%), physical violence $(6.3 \%)$, sexual violence $(3.6 \%)$ and so forth (Lee \& Shin, 2013). It was found that verbal abuse accounted for $90.6 \%$, which was biggest part, of violence experienced by nurses in medical institutions (Kwon et al., 2007). Such experiences of verbal abuse repressively control a victim's emotions and lead to groundless feelings of humiliation and frustration (Nam et al., 2005). In addition, violence experiences of nurses include two types, horizontal violence from colleagues of same 
positions and vertical violence from superiors or doctors using negative words (Cho, 2012). After effects of verbal abuse include emotional turmoil, shrinking interpersonal relationships along with communication breakdowns, loss of an individual's self-esteem, restriction of communication and so forth. As such, it was found that workplace violence could result in not only physical and mental damage but also employee turnover (Kim, 2018). It was also found that most of the people who have experienced violence not only feel anger, sadness, disappointment and fear and thus are afraid of facing customers but also lose interest in their work (Arnetz \& Arnetz, 2001; Carroll, 1999).

In this study, the scales used in Kim (2018) and Nam et al. (2005), customer- and workplace-related elements, were revised and supplemented to classify external and internal violence and give modified definitions.

\section{Resilience}

Resilience has been deemed to be associated with an individual's developmental strengths and positive attitudes for resilient responses to changes and environments upon relative changes in situations (Masten, 2001; Do, 2009). Resilience is an ability to successfully overcome individual hardships by keeping a positive mindset which is a protective factor exposed against hardships to reduce negative effects and cope flexibly with conditions (Jeong, 2017). The term resilience was first used to describe materials with elastic properties (Olsson et al., 2003) but is being widely used to explain the characteristics of those not affected physically or mentally by whatever hardships they face. At the initial stage of research on resilience, it was used as the major concept for describing the way adolescents in difficult situations cope with and get over such situations (Garmezy, 1991). Afterwards, many researchers began using the term resilience in research on stress responses and derived results about new situations to be handled (Do, 2008; Olsson et al., 2003).

Won (2011) demonstrated that factors needed to raise the level of psychological well-being help university students prepare for their complicated lives through social support and develop a positive mindset into subjective well-being. Kim (2015) demonstrated the possibility that solving problems by controlling life stress has a positive influence on mental health and quality of life. Besides, it was found that people with higher hopes were more likely to construct coping strategies to overcome stressful situations. Such a personal tendency makes people demonstrate their flexibility to cope with difficult situations flexibly with positive attitudes.

In this context, the scales used in Jang (2018) and Jeong (2017), which apply an individual's ability to adapt to and

Table 1. Measurement scales

\begin{tabular}{|c|c|c|c|c|c|}
\hline Factor & & Item & $\begin{array}{l}\text { Number of } \\
\text { questions }\end{array}$ & Scale & Reference \\
\hline \multirow{2}{*}{$\begin{array}{l}\text { Violence } \\
\text { experience } \\
\text { Violence } \\
\text { experience }\end{array}$} & $\begin{array}{l}\text { External violence } \\
\quad \text { (Customer- } \\
\text { related area) }\end{array}$ & $\begin{array}{l}\text { Swear words in anger, crude language and words that } \\
\text { hurt feelings, threatening words with threats, sarcastic } \\
\text { language about physical appearance, demeaning } \\
\text { language about academic or personal background, } \\
\text { crude language or offensive words to superiors, } \\
\text { colleagues or junior colleagues. }\end{array}$ & 6 & \multirow{2}{*}{$\begin{array}{l}5 \\
- \text { point } \\
\text { Likert } \\
\text { scale }\end{array}$} & \multirow{2}{*}{$\begin{array}{l}\text { Kim }(2018) \text { and Nam } \\
\text { et al. (2005), revised } \\
\text { and supplemented }\end{array}$} \\
\hline & $\begin{array}{l}\text { Internal violence } \\
\text { (Workplace- } \\
\text { related area) }\end{array}$ & $\begin{array}{l}\text { Emotionally abusive words, words that hurt feelings } \\
\text { and crude language, disparaging remarks about } \\
\text { occupation, oppressive words (disrespectful words } \\
\text { about position or authority), words evoking sexual } \\
\text { humiliation, sarcastic language about physical } \\
\text { appearance, disrespectful words about ability, words } \\
\text { creating a warlike atmosphere, from superiors. }\end{array}$ & 8 & & \\
\hline Resilience & \multicolumn{2}{|c|}{$\begin{array}{l}\text { Motivation to achieve goals, independent job performance, recovery from } \\
\text { hardships by oneself, quick adaptation to new changes, effort to enjoy } \\
\text { overcoming hardships. }\end{array}$} & 5 & $\begin{array}{l}5 \\
\text {-point } \\
\text { Likert } \\
\text { scale }\end{array}$ & $\begin{array}{l}\text { Hong et al. (2019), } \\
\text { Jang (2018), Kim } \\
(2017) \text { and Jeong } \\
\text { (2017), revised and } \\
\text { supplemented }\end{array}$ \\
\hline
\end{tabular}

General characteris-tics
Gender, age, marital status, educational attainment and income.

5 
overcome hardships in a positive way, were revised and supplemented to classify the components of hair and beauty industry workers' recovery from stress into motivation to achieve their goals, independent job performance capability, ability to overcome hardships by themselves and so forth, and give modified definitions.

\section{Materials and Methods}

\section{Research Hypothesis}

H1. There are differences in violence experiences associated with the general characteristics of hair and beauty industry workers.

H2. There are differences in resilience associated with the general characteristics of hair and beauty industry workers.

H3. Violence experiences of hair and beauty industry workers have an influence on resilience.

\section{Research Subject and Data Collection}

The subjects were selected among male and female hair and beauty industry workers in their 20s, 30s, 40s from Gangbuk and Gangnam District of Seoul Metropolitan City. A total of 247 questionnaires, excluding 53 with insincere responses out of 300 , obtained from a survey conducted from
August 1 to September 30, 2020 including sample subjects who gave voluntary consent were finally analyzed.

\section{Measurement scales}

The measurement scales consist of 24 questions in total including 12 about violence experiences and 5 about resilience of an individual to cope with violence, revised and supplemented in this study based on previous studies, and 5 about general characteristics, based on the 5-point Likert scale.

\section{Data Analysis}

Analysis of collected data was performed using SPSS 21.0 according to the following process: Firstly, frequency analysis was performed to understand the general characteristics of research subjects, and secondly, Cronbach's alpha was calculated to measure the reliability of violence experiences and resilience. In addition, descriptive statistics analysis was performed to calculate the mean and standard deviation of violence experiences and resilience, and statistically significant differences in violence experiences resilience caused by the general characteristics of the subjects were estimated by conducting t-test, one-way ANOVA and Scheffe's multiple comparison procedure with a significance level of 0.05 . Besides, correlation analysis was performed to determine the

Table 2. General characteristics of research subjects $(\mathrm{N}=247)$

\begin{tabular}{|c|c|c|c|}
\hline & Factor & Frequency $(\mathrm{N})$ & Percentage $(\%)$ \\
\hline \multirow{2}{*}{ Gender } & Male & 72 & 29.1 \\
\hline & Female & 175 & 70.9 \\
\hline \multirow{3}{*}{ Age } & $20 \mathrm{~s}$ & 72 & 29.1 \\
\hline & $30 \mathrm{~s}$ & 126 & 51.0 \\
\hline & $40 \mathrm{~s}$ & 49 & 19.8 \\
\hline \multirow{2}{*}{ Marital status } & Married & 111 & 44.9 \\
\hline & Unmarried & 136 & 55.1 \\
\hline \multirow{4}{*}{ Educational attainment } & High school graduates & 72 & 29.1 \\
\hline & Vocational college graduates & 82 & 33.2 \\
\hline & College graduates & 63 & 25.5 \\
\hline & People who have postgraduate degrees & 30 & 12.1 \\
\hline \multirow{5}{*}{ Monthly income } & Under 1.5-2 million KRW & 62 & 25.1 \\
\hline & Under 2-3 million KRW & 86 & 34.8 \\
\hline & Under 3-4 million KRW & 84 & 34.0 \\
\hline & 4 million KRW or more & 15 & 6.1 \\
\hline & Total & 247 & 100.0 \\
\hline
\end{tabular}


relationship between violence experiences and resilience, and multiple regression analysis was performed to understand the influence of violence experiences on resilience.

\section{Results and Discussion}

\section{General Characteristics of Research Subjects}

The general characteristics of research subjects are shown in $<$ Table $2>$.

With respect to gender, 'males' and 'females' accounted for $29.1 \%$ and $70.9 \%$ of the entire subjects, respectively. As to age, people in their ' $30 \mathrm{~s}$ ' accounted for $51.0 \%$ of the entire subjects, followed by those in their ' $20 \mathrm{~s}$ ' and ' 40 s' or more accounting for $29.1 \%$ and $19.8 \%$, respectively. As to marital status, 'married' and 'unmarried' people accounted for $44.9 \%$ and $55.1 \%$, respectively. As to educational attainment, 'vocational college graduates' accounted for $33.2 \%$, followed by 'high school graduates', 'college graduates' and 'people who have postgraduate degrees' accounting for $29.1 \%$, $25.5 \%$, and $12.1 \%$, respectively. As to monthly income, people with monthly income of 'under 2-3 million KRW' accounted for $34.8 \%$, followed by those with monthly income of 'under 3-4 million KRW', 'under 1.5-2 million KRW' and '4 million KRW or more' aaccounting for $34.0 \%, 25.1 \%$, and $6.1 \%$, respectively.

\section{Reliability Test of Measurement Scales}

Reliability, one of the measurement scales used in this study, was analyzed with Cronbach's alpha, and the results of the analysis are shown in the following $<$ Table $3>$.

The reliability of violence experiences and resilience showed a high level, with Cronbach's alpha of 0.682 and 0.994, respectively, considering Cronbach's alpha of 0.6 or over indicates an acceptable level of reliability.

\section{Violence Experiences and Resilience}

The mean and standard deviation of violence experiences and resilience are shown in $<$ Table $4>$.

The grand mean of the factor violence experiences was 4.06, where the sub-factor external violence had a higher mean value of 4.14 than internal violence with a value of 3.95 , while the grand mean of the factor resilience was 3.56 .

\section{Hypothesis Testing}

H1. Differences in violence experiences associated with the general characteristics of hair and beauty industry workers.

The results of testing for differences in violence experiences associated with the general characteristics of the research subjects are shown in $<$ Table $5>$.

There were statistically significant differences in violence experiences associated with age and marital status, but no significant differences associated with gender, educational attainment and monthly income of the subjects at a significance level of 0.05 . With respect to age, people in their 40s $(M=3.89)$ were found to have the lowest level of violence

Table 3. Reliability test

$(\mathrm{N}=247)$

\begin{tabular}{cccc}
\hline Factor & Sub-factor & Number of questions & Cronbach's $\alpha$ \\
\hline Violence & External violence & 6 & .647 \\
experiences & Internal violence & 8 & .633 \\
\hline & Violence experiences & 14 & .682 \\
\hline & Resilience & 5 & .994 \\
\hline
\end{tabular}

Table 4. Mean and standard deviation of violence experiences and resilience

\begin{tabular}{ccccccc}
\hline & Factor & $\mathrm{N}$ & Min. & Max. & Mean & Stand \\
\hline \multirow{2}{*}{$\begin{array}{c}\text { Violence } \\
\text { experiences }\end{array}$} & External violence & 247 & 2.67 & 5.00 & 3.95 & .53 \\
& Internal violence & 247 & 2.13 & 5.00 & 4.14 & .45 \\
\hline & Violence experiences & 247 & 2.36 & 4.93 & 4.06 & .38 \\
\hline & Resilience & 247 & 2.00 & 5.00 & 3.56 & .86 \\
\hline
\end{tabular}


Table 5. Differences in violence experiences associated with the general characteristics of hair and beauty industry workers

$(\mathrm{N}=247)$

\begin{tabular}{|c|c|c|c|c|c|c|c|}
\hline & Factor & $\mathrm{N}$ & Mean & $\begin{array}{l}\text { Standard } \\
\text { deviation }\end{array}$ & $\mathrm{t} / \mathrm{F}$ & $\mathrm{p}$ & Scheffe \\
\hline \multirow{2}{*}{ Gender } & Male & 72 & 4.09 & .40 & \multirow{2}{*}{.822} & \multirow{2}{*}{.412} & \multirow{2}{*}{-} \\
\hline & Female & 175 & 4.05 & .37 & & & \\
\hline \multirow{3}{*}{ Age } & 20s (a) & 72 & 4.10 & .33 & \multirow{3}{*}{$6.236^{* *}$} & \multirow{3}{*}{.002} & \multirow{3}{*}{$\mathrm{b}, \mathrm{a}>\mathrm{c}$} \\
\hline & $30 \mathrm{~s}(\mathrm{~b})$ & 126 & 4.10 & .38 & & & \\
\hline & 40 s or over $(c)$ & 49 & 3.89 & .40 & & & \\
\hline \multirow{2}{*}{ Marital Status } & Married & 111 & 4.15 & .32 & \multirow{2}{*}{$3.208^{* *}$} & \multirow{2}{*}{.002} & \multirow{2}{*}{-} \\
\hline & Unmarried & 136 & 3.99 & .41 & & & \\
\hline \multirow{4}{*}{$\begin{array}{l}\text { Educational } \\
\text { attainment }\end{array}$} & High school graduates & 72 & 4.09 & .30 & \multirow{4}{*}{.576} & \multirow{4}{*}{.631} & \multirow{4}{*}{-} \\
\hline & Vocational college graduates & 82 & 4.03 & .27 & & & \\
\hline & College graduates & 63 & 4.09 & .50 & & & \\
\hline & People who have postgraduate degrees & 30 & 4.01 & .50 & & & \\
\hline \multirow{3}{*}{$\begin{array}{l}\text { Monthly } \\
\text { income }\end{array}$} & Under 2 million KRW & 62 & 4.03 & .46 & \multirow{3}{*}{2.512} & \multirow{3}{*}{.083} & \multirow{3}{*}{-} \\
\hline & Under 2-3 million KRW & 86 & 4.13 & .32 & & & \\
\hline & 3 million KRW or more & 99 & 4.02 & .37 & & & \\
\hline
\end{tabular}

experiences $(\mathrm{F}=6.236, \mathrm{p}<.01)$, followed by those in their $20 \mathrm{~s}$ $(\mathrm{M}=4.10)$ and $30 \mathrm{~s}(\mathrm{M}=4.10)$. As to marital status, married people $(\mathrm{M}=4.15)$ were found to have a higher level of violence experiences than unmarried people $(\mathrm{M}=3.99)$ $(\mathrm{t}=3.208, \mathrm{p}<.01)$. Such results indicate that work continuity based on a long career leads to a high level of violence experience considering the job characteristics in the hair and beauty industry. Besides, the higher level of violence experiences of younger people may be the consequence of their insufficient performance regarding techniques and communication skills.

Lee et al. (2018) found contradictory results from this study regarding educational attainment, while results about general violence experiences associated with age and marital status supported the results of this study. Besides, Jeong (2016) found that $72.5 \%$ and $14 \%$ of nurses in the emergency room respectively had experienced external violence from patients or carers and internal violence from doctors and superiors. Jeong (2017) found that nurses who showed low job performance due to lack of their professional knowledge and techniques had a high level of experiences of verbal abuse from their superiors or colleagues. Thus, since work experiences are necessary in the hair and beauty industry, younger people who have insufficient professional knowledge and techniques are likely to have a higher level of verbal and psychological violence experiences in the workplace compared to older people.
H2. Differences in resilience associated with the general characteristics of hair and beauty industry workers.

The results of testing for differences in resilience associated with the general characteristics of the research subjects are shown in $<$ Table $6>$.

There were statistically significant differences in violence experiences associated with marital status, but no significant differences associated with gender, age, educational attainment and monthly income of the subjects (at a significance level of 0.05 ). With respect to marital status, married people $(M=3.69)$ were found to have a higher level of resilience than unmarried people $(\mathrm{M}=3.46)(\mathrm{t}=2.157, \mathrm{p}<.05)$. Such results indicate that the reason married people can recover more quickly than unmarried one by long experience in work and a wide mind of understanding through experiencing various problems around. Jang (2018) demonstrated that a high level of resilience is shown by people with clear goals and strong wills who can manage stressful situations wisely and those with higher positions who have an ability to manage their stress effectively. Besides, Kim (2020) suggested that resilience to depression and stress increases with high life satisfaction and good relationships with friends. Hong (2018) and Jang (2018) found that high levels of emotional selfawareness, emotional self-control, interpersonal relationships, environments and so forth lead to high resilience. 
Table 6. Differences in resilience associated with the general characteristics of hair and beauty industry workers

$(\mathrm{N}=247)$

\begin{tabular}{|c|c|c|c|c|c|c|c|}
\hline & Factor & $\mathrm{N}$ & Mean & $\begin{array}{r}\text { Standard } \\
\text { deviation }\end{array}$ & $\mathrm{t} / \mathrm{F}$ & $\mathrm{p}$ & Scheffe \\
\hline \multirow{2}{*}{ Gender } & Male & 72 & 3.56 & .85 & \multirow{2}{*}{-.019} & \multirow{2}{*}{.985} & \multirow{2}{*}{-} \\
\hline & Female & 175 & 3.56 & .86 & & & \\
\hline \multirow{3}{*}{ Age } & $20 \mathrm{~s}(\mathrm{a})$ & 72 & 3.64 & .91 & \multirow{3}{*}{.651} & \multirow{3}{*}{.522} & \multirow{3}{*}{-} \\
\hline & $30 \mathrm{~s}(\mathrm{~b})$ & 126 & 3.56 & .82 & & & \\
\hline & 40s or over (c) & 49 & 3.46 & .87 & & & \\
\hline \multirow{2}{*}{ Marital Status } & Married & 111 & 3.46 & .81 & \multirow{2}{*}{$2.157^{*}$} & \multirow{2}{*}{.032} & \multirow{2}{*}{-} \\
\hline & Unmarried & 136 & 3.69 & .88 & & & \\
\hline \multirow{4}{*}{$\begin{array}{l}\text { Educational } \\
\text { attainment }\end{array}$} & High school graduates & 72 & 3.54 & .79 & \multirow{4}{*}{1.441} & \multirow{4}{*}{.231} & \multirow{4}{*}{-} \\
\hline & Vocational college graduates & 82 & 3.45 & .91 & & & \\
\hline & College graduates & 63 & 3.74 & .82 & & & \\
\hline & People who have postgraduate degrees & 30 & 3.55 & .92 & & & \\
\hline \multirow{3}{*}{ Monthly income } & Under 2 million KRW & 62 & 3.51 & .96 & \multirow{3}{*}{1.433} & \multirow{3}{*}{.241} & \multirow{3}{*}{-} \\
\hline & Under 2-3 million KRW & 86 & 3.69 & .81 & & & \\
\hline & 3 million KRW or more & 99 & 3.49 & .82 & & & \\
\hline
\end{tabular}

\section{A correlation between violence experiences and resilience}

The results of testing for a correlation between violence experiences and resilience are shown in $\langle$ Table 7$\rangle$.

It was found that resilience had positive correlations with internal violence $(\mathrm{r}=.365, \mathrm{p}<.001)$ and external violence $(\mathrm{r}=.355, \mathrm{p}<.001)$.
H3. Violence experiences would have an influence on resilience.

The results of regression analysis on the influence of violence experiences on resilience are shown in $\langle$ Table $8>$.

The coefficient of determination $\left(\mathrm{R}^{2}\right)$ suggested that $21 \%$ of variance was explained by a regression model, which indicated a statistically significant correlation $(\mathrm{F}=32.400, \mathrm{p}<.001)$. With

Table 7. Correlation between violence experiences and resilience

\begin{tabular}{|c|c|c|c|c|c|}
\hline \multirow{2}{*}{\multicolumn{2}{|c|}{ Factor }} & \multicolumn{3}{|c|}{ Violence experiences } & \multirow{2}{*}{ Resilience } \\
\hline & & External violence & Internal violence & Sum & \\
\hline \multirow{2}{*}{$\begin{array}{c}\text { Violence } \\
\text { experiences }\end{array}$} & External violence & 1 & & & \\
\hline & Internal violence & $.235^{* * *}$ & 1 & & \\
\hline \multicolumn{2}{|c|}{ Violence experiences } & $.753^{* * *}$ & $.817^{* * *}$ & 1 & \\
\hline \multicolumn{2}{|c|}{ Resilience } & $.355^{* * *}$ & $.365^{* * *}$ & $.458^{* * *}$ & 1 \\
\hline
\end{tabular}

Table 8. Influence of violence experiences on resilience

$(\mathrm{N}=247)$

\begin{tabular}{cccccccc}
\hline & \multirow{2}{*}{ Factor } & \multicolumn{5}{c}{ Dependent variable : Resilience } \\
\cline { 2 - 8 } & Constant & $\mathrm{B}$ & Standard error & $\beta$ & $\mathrm{t}$ & $\mathrm{t}$ & $\mathrm{V}$ \\
\hline \multirow{2}{*}{$\begin{array}{c}\text { Violence } \\
\text { experiences }\end{array}$} & External violence &. .625 & .526 & .1 .189 & .236 & \\
\hline & Internal violence & .568 & .111 & .298 & $5.096^{* * *}$ & .000 & 1.058 \\
\hline${ }^{* * *} \mathrm{p}<.001$ & $\mathrm{R}^{2}=.210$, adj $\mathrm{R}^{2}=.203, \mathrm{~F}=32.400^{* * *}$ & & & \\
\hline
\end{tabular}


respect to each independent variable, experiences of internal violence $(\beta=.298, p<.001)$ and external violence $(\beta=.285$, $\mathrm{p}<.001)$ were found to have a statistically significant influence on resilience. Therefore, it was found that the higher the level of internal and external violence experiences, the higher the level of resilience.

\section{Conclusion}

The purpose of this study is to test resilience of hair and beauty industry workers who experienced violence in association with differences in demographic characteristics, which suggested the following results.

First, testing for differences in violence experiences associated with general characteristics found that people in their 40s had the lowest level of internal violence experiences, followed by those in their 20s and 30s. In terms of age, it was suggested that people in their 20s are likely to go through stress and psychological violence caused by their superiors or colleagues in the workplace due to their short experience in work, while those in their 30s and 40s are exposed to psychological violence depending on the intensity of their face-to-face customer services. In terms of marital status, a higher level of violence experiences of married people than unmarried people can be deemed the consequence of longer time of violence experiences accumulated during their longer career along with the possibility of additional violence experiences related to domestic and other circumstances.

Second, testing for differences in resilience associated with general characteristics found that married people showed a higher level of resilience than unmarried people. This result may be associated with the characteristics of hair and beauty industry where long work experience and skilled techniques are necessary. Therefore, an individual's ability to communicate skillfully with customers and handle their work seems to be the result of long work experience.

In this context, the results of this study demonstrate that hair and beauty industry workers need to be protected from their work environment based on the formation of proper relationships in relation to their job autonomy considering the nature of their work. Besides, an informal atmosphere and positive communication are necessary between those workers and their superiors or colleagues at the workplace. Therefore, there is a need for the development of programs for the recovery of hair and beauty industry workers' physical and mental health caused by many kinds of hard work and services for customer satisfaction and the activation of educational programs as well as technical training courses in hair salons and beauty academies.

There was a limit in generalizing a distribution ratio among the subjects of this study due to regional restrictions in the subjects and their component ratio. Therefore, the scope of research needs to be extended in terms of environment in further work for a more detailed study.

\section{References}

Arnetz, J. E., \& Arnetz, B. B. (2001). Violence toward health care staff and possible effects on the quality of patient care. Social Science of Medicine. 52, 417-427.

Bae, H. J. (2012). A study on verbal violence experience, job stress and turnover intention among operating room nurses. Eulji University Graduate School. 6-7.

Cho, J. A. (2012). Impact of exposure to verbal abuse on nurse's burn out and organizational commitment at hospital. Catholic University of Pusan Graduate School (Master's Thesis). 4.

Carrol, V. (1999). Workplace violence. American J of Nur. 99(3), 60.

Do, N. H. (2009). Resilient adolescents from youth-headed families: social competence and subjective well-being. Yonsei University Graduate School (Doctoral Dissertation). 10-21.

Garmezy, N. (1991). Resilience in children's adaptation to negative life events and stressed environments. Pediatric Annals. 20, 459466.

Hong, J. A., \& Hong, B. G. (2019). The effects of resilience on turnover intention in hair salon employees : focusing on the mediating effects of job stress. Journal of Korea Design Forum. 24(1), 33-48.

Hong, G. M., Lee, G. M., \& Jang, S. R. (2019). Violence Experience among Wage Workers in the Workplace and Related Factors in Korea. Health and Social Welfare Review, 39(3), 506-534.

Jang, S. G. (2018). The effects of resilience on happiness in beauty industry employees. Konkuk University Graduate School (Doctoral Dissertation). 115-117.

Jeong, E. (2017). A meta-analysis of the variables related to resilience in adolescence. Chodang University Graduate School (Doctoral Dissertation). 7-18.

Jeong, H. J. (2017). A study on relationship between verbal violence experience, job stress, and resilience and communication ability of operating room nurses. Kyung Hee University Graduate School (Master's Thesis). 7-9.

Jeong, I. Y. (2016). Effect on the nursing performance through coping behavior after the violence experiencing form nurses in the emergency room. Gachon University Graduate School of Nursing (Master's Thesis). 49-52.

Kwon, H. J., Kim, H. S., Choi, G. S., Lee, G. S., \& Sung, Y. H. (2007). A Study on verbal abuse experience at medical centers. 
Journal of Korean Clinical Nursing Research, 13(2), 113-124.

Kang, M. J., \& Park, I. S. (2015). Types of violence and coping methods experienced by general hospital nurses. Journal of Korean Clinical Nursing Research, 21(1), 92-104.

Kim, C. Y. (2002). Study on the workplace harassment against women and a new mode of employment discrimination. Ewha Womans University Graduate School (Master's Thesis). 9-11.

Kim, H. W. (2014). The effects of group art therapy on psychological well-being of beauty service workers. Pyeongtaek University Graduate School of Counseling (Master's Thesis). 12.

Kim, I. S. (2015). The effect of group art therapy program on the stress-coping ability and problem-solving ability of children of single parent. Korean Journal of Art Therapy, 22(2), 479-50.

Kim, J. J., \& Kang, G. Y. (2020). Depression and stress, the resilience of a in office workers. Journal of Industrial Convergence, $18(2), 51-57$.

Kim, Y. S. (2018). The influence of verbal violence experience, job stress, and burnout on turnover intention of operating room nurses. Kyung Hee University Graduate School. 9.

Lee, E. G., Lim, H. G., \& Yang, E. J. (2018). The effect of hair salon workers' coping after experiencing violence on work performance. Journal of The Korean Society of Cosmetology, 24(4), 770-778.

Lee, H. R., \& Shin, M. G. (2013) Factors affecting post traumatic stress disorder of the verbal violence experienced nurses. Journal of the Korea Society of Health Informatics and Statistics, $38(1), 15-25$.
Lee, S. J., \& Kim, J. S. (2017). Convergence study on relationship among verbal violence experience, verbal violence impact and burnout in operating room nurses. Journal of the Korea Convergence Society, 8(6), 85-96.

Lim, Y. S. (2014). The correlation between violence experiences, violence responses and job stress of 119 paramedics. Gongju University Graduate School (Master's Thesis). 21.

Masten, A. S., \& Costs worth, J. D. (2001). The development of competence in infavorable and unfavorable environments. American psychologist, 53(2), 205-220.

Nam, K. D., Yoon, G. S., Chung, H. S., Park, S. A., Jang, B. Y., Kim, H. R., Ohm, H. S., \& Sung, Y. H. (2005). A Study on the Development of Verbal Abuse Scale for Operating Room Nurses. Journal of Korean Academy of Nursing Administration. 11(2), 159-172.

Olsson, C. A., Bond, L., Burns, J., Vella-Brodrick, D. A., \& Sawyer, S. M. (2003). Adolescent resilience: A concept analysis. Journal of Adolescence, 26, 1-11.

Won, D. R. (2011). The effect of social support, hope and problemsolving coping on the psychological well-being of adolescents: the mediating role of hope and problem-solving coping. Korean Journal of Psychology, 16(2), 297-311.

Wu, J. J., \& Seo, E. J. (2018). Experience of violence in clinical practice and self-esteem among college nursing students. Asiapacific Journal of Multimedia Services Convergent with Art, Humanities, and Sociology, 8(6), 305-313. 